\title{
CLASSIFICATION OF LAND CAPABILITY IN MANOKWARI AREA USING GEOGRAPHIC INFORMATION SYSTEM (GIS)
}

\author{
Brenda Blanfia Fonataba ${ }^{1}$, Prima Jiwa Osly ${ }^{1}$, Irfan Ihsani ${ }^{1}$ \\ ${ }^{1}$ Civil Engineering Department, Faculty of Engineering, Pancasila University \\ E-mail: brenda.fonataba@gmail.com
}

Received $4^{\text {th }}$ October 2020, Accepted $25^{\text {th }}$ October 2020

\begin{abstract}
The Land is a natural resource that has limitations to accommodate human activities in land use. Utilization of land for residential land, regional development or, other land uses sometimes creates many environmental problems such as degradation of land quality and disturbance of natural balance. The increasing need for and competition in land use for regional development in Manokwari Regency requires careful thought in making decisions about the most beneficial use of limited land resources. Land Capability Classification is directed to determine the potential of land for broad land use based on suitable methods of use. The research variables used are nine Land Capability Units (LCU), namely LCU Morphology, LCU Slope Stability, LCU for Foundation Stability, LCU Water Availability, LCU Ease of Doing, LCU Against Erosion, LCU for Waste Disposal, LCU for Drainage and LCU for Natural Disasters. All LCU are analyzed using input in the form of factors limiting land capability consisting of maps of elevation, slope, soil type, rainfall, watershed, geology, natural disasters, and land use. The analysis produces an output in the form of a land capability classification map from the results of the digital spatial analysis process using a Geographical Information System (GIS). Through a weighting system based on secondary data obtained, It can be seen that the research area is divided into 4 classes of land capability, namely poor, moderate, sufficient, and high development capability.
\end{abstract}

Keywords: Regional Development, Land Capability Classification, Manokwari Regency, Geographic Information System (GIS) 


\section{INTRODUCTION}

Natural resources are an important source in our environment and they can be used for various interests and needs of human life in order to be more prosperous (Gottfried, 1992; Chowdhury, 2014). We can find natural resources anywhere, such as in soil, water, land surface, and air. Based on the nature of renewal, there are two types of natural resources, namely renewable resources and non-renewable resources (Chowdhury, 2014). Renewable means that it can be used repeatedly such as water, animals, forest products and others, whereas we cannot recycle and conserve non-renewable resources so that it will eventually become destroys.

The government realizes that Indonesia's natural resource wealth is an important capital in implementing national development (Marpaung, 2008). To increase state revenue and foreign exchange (state revenue), so the development is linked to the pursuit of economic growth development targets. Because of this reason, the usage of natural resources is sometimes carried out without paying attention to the sustainability of its function, which can rise to degradation in quality and quantity. The land is a non-renewable natural resource that has a high level of degradation with a very slow regeneration process (FAO, 2007). Land is part of a landscape that includes the notion of the physical environment including soil, climate, topography, and even the state of natural vegetation, all of which will potentially have a wider effect including those that have been influenced by various activities of flora, fauna, and humans in the past as well as in the present, such as reclaimed swamp and tidal lands or soil conservation measures in certain areas (Djaenudin et al, 2003). As an agrarian country, Indonesia has potential natural resources that are used for growing media for plant. The utilization of natural resources is needed to conform with its agro ecological condition so the farming business can be sustainable (Osly et al, 2019). Other side Indonesia is a developing country, however land for regional development is a natural resource that has limitations in accommodating human activities in exploiting natural resources. There are so many examples of cases of loss caused by inappropriate land use that exceeds its capacity. People must manage the land wisely to give the best result and to keep its enviromental protection. (Arifin, 2001; Alikodra 2012; Maryati, 2013; Abdel Rahman et al. 2016).

Sometimes it creates many environmental problems in land use, either for residential land, area development or other land uses, such as degradation of land quality and disturbance of natural balance. (Alvarado, 2017; Alikodra 2012). Every ecosystem has a function in maintaining environmental balance. If an ecosystem is damaged, then the environment will become unbalanced and natural disasters that cannot be predicted by humans. That is why it is necessary to recognize as early as possible the physical characteristics of a zone or area to be developed, both the potential for its natural resources and the disaster-prone it contains, which are then translated as potentials and constraints for zone or regional development.

Physical and environmental analysis of the area is carried out to meet the needs of these natural resources, with management capabilities and land suitability, so that land use in regional development can be carried out optimally while still paying attention to the balance of the ecosystem (Minister of Public Works Regulation No. 20/PRT/M/2007).

Land capability used as a methodology for land use planning was first made by the USDA (United States Department of Agriculture) to control soil erosion, and then developed as the land capability classification system. Currently the land capability classification has been used for land evaluation for various purposes in various countries around the world (Sitorus, 2010).

One of the efforts utilize land resources according to their potential is the Classification of land capability. It needs to assess land potential, especially in the framework of policy formulation, land use, and sustainable land management. Maps are needed to formulate policies, one of them is the land capability map.

One of the efforts to use land resources according to their potential is the classification of land capabilities. The potential of land needs to be studied, especially in the framework of policy formulation, land use, and sustainable land management. Maps are needed to formulate policies, one of which is a map of land capability. Manokwari was chosen as the research location because there was no complete information in the study about classification of land capability in Manokwari Regency. The existing maps are still partial and do not yet summarize the 9 Land Capability Units that must be identified in accordance with the Minister of Public Works Regulation Number 20 of 2007.

Based on the information above, it needs to research on the classification of land capability in the Manokwari Regency area. Manokwari Regency is the capital of West Papua Province, which is one of the developing districts. The development of Manokwari district can be seen from the increasing population and economy (Osly et al, 2019). The purpose of the research is to determine the land capability class and make a land capability classification map as well as 
provide data and information about the land capability class in the Manokwari Regency area to the community and government in managing land resources in the area.

\section{METHOD}

The location of the research is located in Manokwari Regency area. Manokwari is the capital city of West Papua Province. Manokwari Regency area consists of 9 districts, 9 subdistricts, and 164 villages. The total population is 185.615 in 2017, with an area of $3.186,28 \mathrm{~km}^{2}$ and with a population distribution of 58 people / $\mathrm{km}^{2}$.

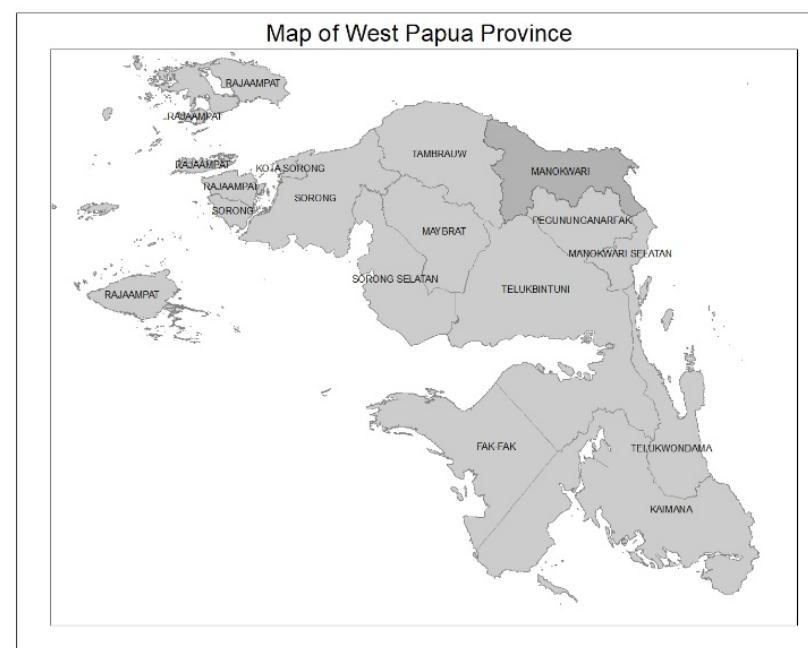

Figure 1. Map of West Papua Province.

The tools and devices used are the Indonesian Earth Map at a scale of 1:50,000; Map of West Papua Province, District Administration Map of Manokwari, Elevation Map of Manokwari, Slope Map of Manokwari, Morphological Map of Manokwari, Soil Types Map of Manokwari, Rainfall Map of Manokwari, Natural Disaster Map of Manokwari, Land Use Map of Manokwari (Development Planning Agency at Sub-National Level/BAPPEDA Manokwari Regency), hardware in the form of a laptop, the software in the form of ArcGIS 10.6 applications, printers, and other writing tools.

The determination of the land capability class is carried out based on the guidelines for the Minister of Public Works Regulation Number 20 of 2007. The data analysis method used in this study is a map overlay (geoprocessing) using a Geographical Information System (GIS). Geographic Information Systems (GIS) techniques have been proved to be helpful and successful tools in studying, mapping, processing, and presenting spatial data, and become an effective tools to evaluate the physical land capability and suitability (Prahasta, 2011; Mary Silpa, 2016; Gashaw, 2018).
The data analysis method needs scoring analysis techniques to provide a value for each characteristic parameter of the variable. Hence, it can calculate the value and can determine the ranking. In this research, there are 9 Land Capability Units (LCU) which become the research variables. The parameters of those variables will be given the ability value of each level in each land capability unit (Minister of Public Works Regulation Number 20/PRT/M/2007). The research variables analyzed are:

1. LCU of Morphology

2. LCU of Slope Stability

3. LCU of Foundation Stability

4. LCU of Water Availability

5. LCU to Against Natural Disaster

6. LCU for Drainage

7. LCU of Waste Disposal

8. LCU to Against Erosion

9. LCU of Ease of Work

The steps to analyze land capability, namely:

1. Conduct land capability unit analysis, to obtain an overview of the capability level of each land capability unit.

2. Determine the capability value of each level on each land capability unit, with an assessment of 5 (five) for the highest value and 1 (one) for the lowest value.

3. Multiply these values by the weight of each unit of land capability. This weight is based on how much the land capability unit affects urban development. The weighting of LCU is in Table 1.

4. Superimpose all the land capability units, by adding up the multiplication result of the value times the weight of all land capability units in one map. Finally, it can get a range of values indicating the value of land capability in the territory and/or area planning.

5. Determine the range of values that will be used as the divider of the land capability classes, so it can obtain the land capability zones with the $X-Y$ value that indicates the level of land capability in this area, and depicted in a land capability classification map for spatial planning. Details are in Table 2 (Minister of Public Works Regulation Number 20/PRT/M/2007).

Classification of land capability carried out by overlapping each land capability unit that has obtained the final value multiplication result (level of land capability in each LCU) with its weighted as one by one in order to obtain a map of the total final value multiplied by the cumulative weight of the entire LCU. The result of multiplying the final value by the weight of each unit, in this analysis is called the score. The score is calculated by the formula:

Score $=$ Final Score $\mathrm{x}$ Weight 
Table 1. Weighting of Land Capability Units (LCU).

\begin{tabular}{|c|l|c|}
\hline Number & Land Capability Units (LCU & Weight \\
\hline 1 & LCU of Morphology & 5 \\
\hline 2 & LCU of Ease of Work & 1 \\
\hline 3 & LCU of Slope Stability & 5 \\
\hline 4 & LCU of Foundation Stability & 3 \\
\hline 5 & LCU of Water Availability & 5 \\
\hline 6 & LCU to Against Erosion & 3 \\
\hline 7 & LCU for Drainage & 5 \\
\hline 8 & LCU of Waste Disposal & 0 \\
\hline 9 & LCU to Against Natural & 5 \\
\hline
\end{tabular}

Source: (Minister of Public Works Regulation Number 20/PRT/M/2007)

Table 2. Value and Class of Land Capability.

\begin{tabular}{|c|c|c|}
\hline $\begin{array}{c}\text { Total } \\
\text { Value }\end{array}$ & $\begin{array}{c}\text { Land } \\
\text { Capability } \\
\text { class }\end{array}$ & $\begin{array}{c}\text { Development } \\
\text { Classification }\end{array}$ \\
\hline $32-58$ & Class a & $\begin{array}{c}\text { Low Development } \\
\text { Capability }\end{array}$ \\
\hline $59-83$ & Class b & $\begin{array}{c}\text { Poor Development } \\
\text { Capability }\end{array}$ \\
\hline $84-109$ & Class c & $\begin{array}{c}\text { Moderat Development } \\
\text { Capability }\end{array}$ \\
\hline $110-134$ & Class d & $\begin{array}{c}\text { Sufficient Development } \\
\text { Capability }\end{array}$ \\
\hline
\end{tabular}

\begin{tabular}{|c|c|c|}
\hline $\begin{array}{c}\text { Total } \\
\text { Value }\end{array}$ & $\begin{array}{c}\text { Land } \\
\text { Capability } \\
\text { class }\end{array}$ & $\begin{array}{c}\text { Development } \\
\text { Classification }\end{array}$ \\
\hline $135-160$ & Class e & $\begin{array}{c}\text { High Development } \\
\text { Capability }\end{array}$ \\
\hline
\end{tabular}

Source: (Minister of Public Works Regulation No.20/PRT/M/ 2007)

\section{RESULT AND DISCUSSION}

Analysis of land capability aims to find out the physical factors of the land that are hindering and does not hamper in order to use the land. The output of this analysis is land capability class map (zoning) consisting of development area which is a description of the level of land capability in the research area. The physical aspects of land capability analyzed are called the Land Capability Unit (LCU).

1. Land Capability Unit of Morphology.

The soil morphological characteristics were dominantly used for the land capability clasiffication. The purpose of Land Capability Unit (LCU) of Morphology is to sort out the shape of the landscape or morphology in the area and/or planning area that can be developed according to its function. In carrying out the morphological analysis, it is necessary to have a slope map and a morphological map that is overlaid using ArcGIS to identify the areas included in that criteria.

Table 3. Unit of Morphological Land Capability in Manokwari Regency.

\begin{tabular}{|l|c|c|c|c|c|}
\hline \multicolumn{1}{|c|}{ District } & Low (Ha) & Poor (Ha) & $\begin{array}{c}\text { Moderat } \\
(\mathbf{H a})\end{array}$ & $\begin{array}{c}\text { Sufficient } \\
(\mathbf{H a})\end{array}$ & $\begin{array}{c}\text { High } \\
(\mathbf{H a})\end{array}$ \\
\hline West Manokwari & & & & 4316 & 3128 \\
\hline South Manokwari & 804 & 3049 & 1251 & 10429 & 4250 \\
\hline North Manokwari & & & & 31429 & 8447 \\
\hline East Manokwari & & & & 318 & 1539 \\
\hline Masni & 4082 & 19763 & 5044 & 8804 & 28583 \\
\hline Prafi & 2444 & 18040 & 2475 & 5897 & 11274 \\
\hline Sidey & 14993 & 27440 & 7301 & 5651 & 16405 \\
\hline Tanah Rubuh & 8147 & 12633 & 3213 & 2887 & 2880 \\
\hline Warmare & 9645 & 16269 & 3559 & 7761 & 6610 \\
\hline TOTAL & 40115 & 97194 & 22843 & 77492 & 83116 \\
\hline
\end{tabular}

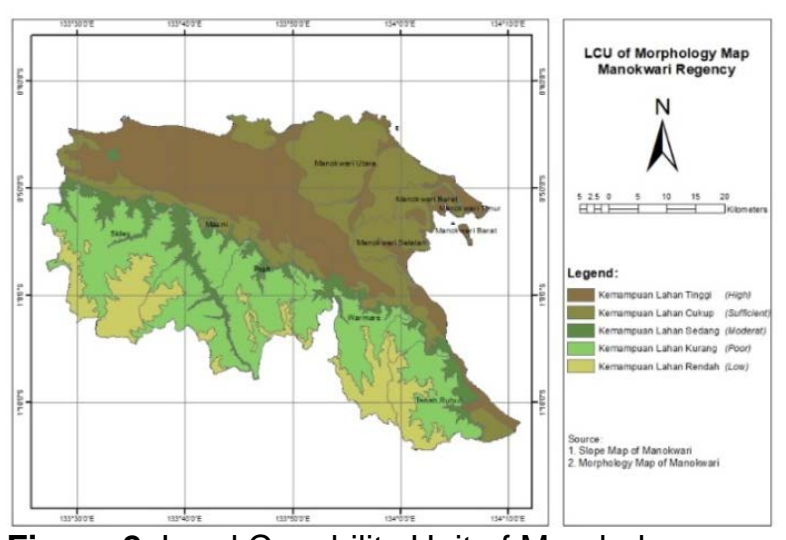

Figure 2. Land Capability Unit of Morphology.
2. Land Capability Unit of Slope Stability.

This slope capability unit analysis was intended to determine land conditions relating to the stability and ease of land development. The stability in this analysis does not take into account the effects caused by the earthquake. The stability that takes into account the effects of the earthquake is analyzed in units of the land capability of the foundation stability. In analyzing slope stability, the input is required in the form of maps of elevation, slope, and morphology, and soil types that will be overlaid using ArcGIS 10.6 and producing an LCU map of Slope Stability. 
Table 4. Land Capability Unit of Slope Stability in Manokwari Regency.

\begin{tabular}{|l|c|c|c|c|c|}
\hline \multicolumn{1}{|c|}{ District } & Low (Ha) & Poor (Ha & Modeerat (Ha) & Sufficient (Ha) & $\begin{array}{c}\text { High (Ha) } \\
3128\end{array}$ \\
\hline West Manokwari & & & & 4316 & 10429 \\
\hline South Manokwari & 804 & 3049 & 1251 & 31439 & 8447 \\
\hline North Manokwari & & & & 318 & 1539 \\
\hline East Manokwari & & & & 8804 & 28583 \\
\hline Masni & 4082 & 19763 & 5044 & 5897 & 11274 \\
\hline Prafi & 102 & 18040 & 2480 & 5687 & 16405 \\
\hline Sidey & 15209 & 27440 & 7300 & 2887 & 2880 \\
\hline Tanah Rubuh & 8147 & 12633 & 3334 & 7761 & 6610 \\
\hline Warmare & 16268 & 16250 & 3559 & 77538 & 83116 \\
\hline TOTAL & 44612 & 97175 & 22968 & & \\
\hline
\end{tabular}

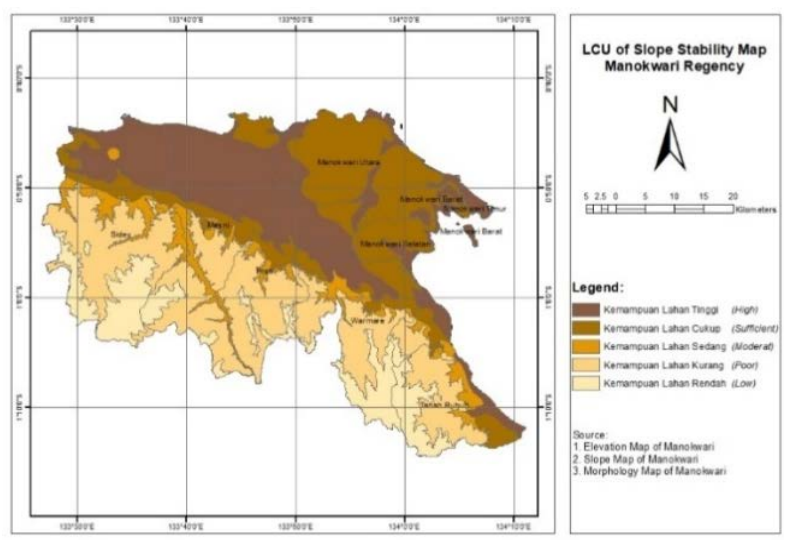

Figure 3. Land Capability Unit of Slope Stability.
3. Land Capability Unit of Foundation Stability. Foundation stability can ensure the building is safe and reliable. Reliability of the building depends not only on the reliability of structural members and the entire structure of the system. There is the aspect of soil to make the analysis of the reliability and stability of the foundation of the issues involved temporarily upper structure. This LCU analysis is intended to determine the level of land capability in supporting residential buildings, offices as well as facilities and infrastructure in supporting land use for settlements. It needs a map of the height, slope, morphology, and soil type in analyzing the stability of the foundation.

Table 5. Land Capability Unit of Foundation Stability in Manokwari Regency.

\begin{tabular}{|l|c|c|c|c|c|}
\hline \multicolumn{1}{|c|}{ District } & Low (Ha) & Poor ((Ha) & Moderat (Ha) & Sufficient (Ha) & High (Ha) \\
\hline West Manokwari & & & & 4315 & 3129 \\
\hline South Manokwari & & & 3153 & 11576 & 4250 \\
\hline North Manokwari & & & & 31439 & 8448 \\
\hline East Manokwari & & & & 318 & 1539 \\
\hline Masni & 4097 & 18869 & 5916 & 9439 & 28007 \\
\hline Prafi & 2356 & 17353 & 3174 & 5950 & 19302 \\
\hline Sidey & 14970 & 26972 & 7363 & 5991 & 16492 \\
\hline Tanah Rubuh & 5 & 8142 & 12887 & 3658 & 5189 \\
\hline Warmare & 4735 & 12884 & 1687 & 9052 & 8260 \\
\hline TOTAL & 26163 & 84220 & 34180 & 81738 & 94616 \\
\hline
\end{tabular}

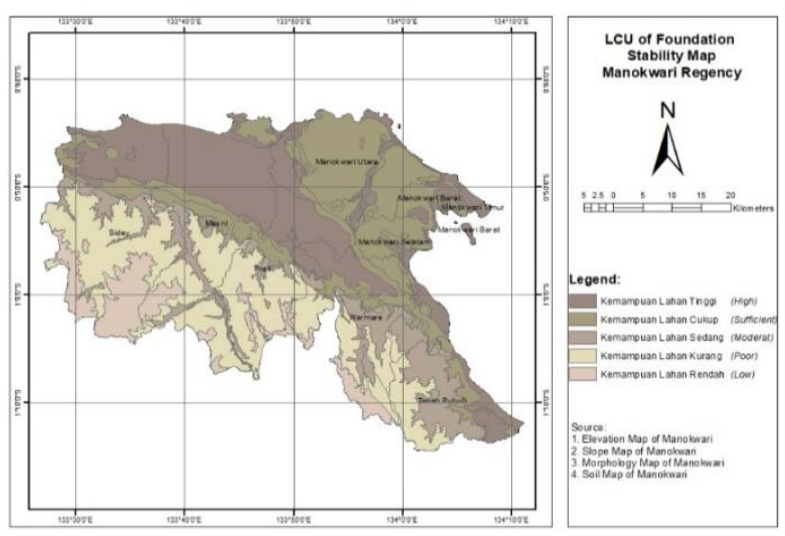

Figure 4. Unit of Land Capability of Foundation Stability
4. Land Capability Unit of Water Availability.

The availability of water in a land is very important, considering the function of ground water as a source of clean water supply for various needs, especially during long droughts where surface water is insufficient. Based on that reason, hence Capacity unit analysis is carried out with the intention of knowing the ability of the land to support water availability.

In analyzing LCU The availability of water requires input in the form of a map of the watershed, rainfall, and land use. 
Table 6. Land Capability Unit of Water Availability in Manokwari Regency.

\begin{tabular}{|l|c|c|c|}
\hline \multicolumn{1}{|c|}{ District } & Poor (Ha) & Moderat (Ha) & Sufficient (Ha) \\
\hline West Manokwari & 5655 & 1836 & \\
\hline South Manokwari & 8793 & 10980 & \\
\hline Nort Manokwari & 29210 & 10725 & \\
\hline East Manokwari & 1397 & 523 & 216 \\
\hline Masni & 29430 & 36876 & \\
\hline Prafi & 2794 & 37343 & \\
\hline Sidey & 24205 & 47672 & 216 \\
\hline Tanah Rubuh & & 29841 & \\
\hline Warmare & 1105 & 42754 & \\
\hline TOTAL & 102589 & 218550 & \\
\hline
\end{tabular}

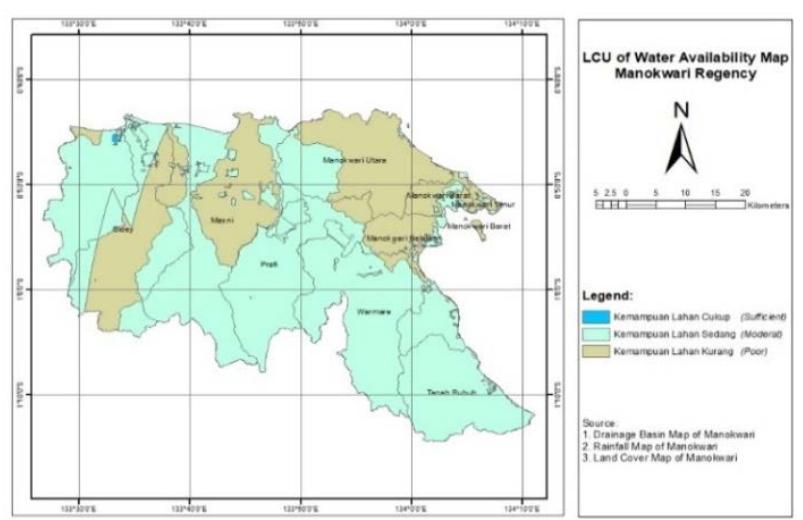

Figure 5. Land Capability Unit of Water Availability.

5. Land Capability Unit to Against Natural Disaster.

Natural disasters are catastrophic events with atmospheric, geological, and hydrological origins (such as droughts, earthquakes, floods, hurricanes, landslides) that can cause fatalities, property damage and social environmental disruption.

LCU analysis of natural disasters is intended to determine land conditions which relates to the ability of the land to the possibility of natural disasters. Early recognition of land that may have the potential for natural disasters will be useful in anticipating natural disaster action efforts or avoid using land that has the potential for natural disasters. In conducting the analysis of LCU for natural disasters, the input is required in the form of a natural disaster hazard map such as earthquakes, floods and others.

Table 7. Land Capability Unit to Against Natural Disaster in Manokwari Regency.

\begin{tabular}{|l|c|c|}
\hline \multicolumn{1}{|c|}{ District } & Moderat (Ha) & High (Ha) \\
\hline West Manokwari & 2819 & 3822 \\
\hline South Manokwari & 13608 & 5052 \\
\hline North Manokwari & 36462 & 3249 \\
\hline East Manokwari & 745 & 1124 \\
\hline Masni & 45149 & 18833 \\
\hline
\end{tabular}

\begin{tabular}{|l|c|c|}
\hline \multicolumn{1}{|c|}{ District } & Moderat (Ha) & High (Ha) \\
\hline Prafi & 27343 & 11639 \\
\hline Sidey & 59078 & 10268 \\
\hline Tanah Rubuh & 28964 & 2138 \\
\hline Warmare & 32164 & 8636 \\
\hline TOTAL & 246332 & 64761 \\
\hline
\end{tabular}

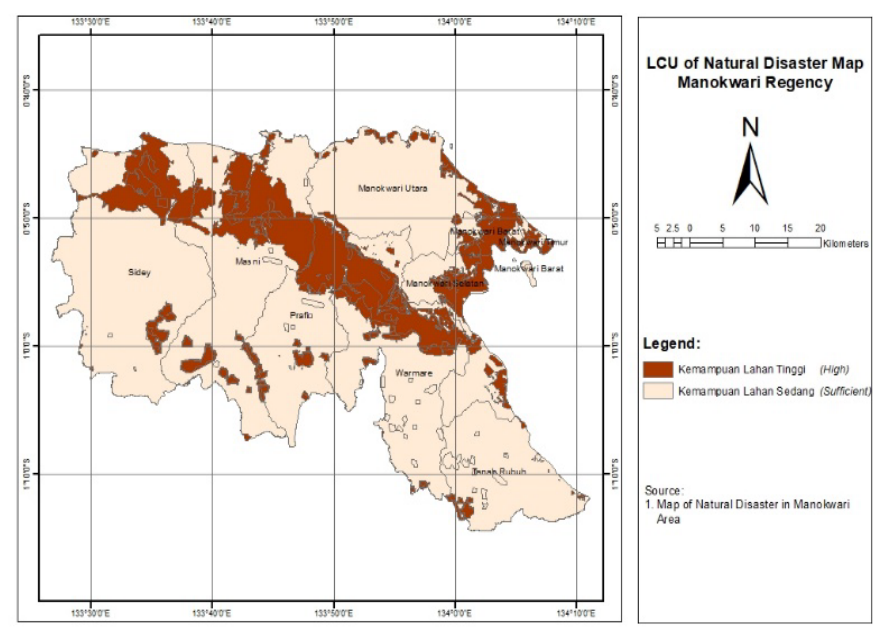

Figure 6. Land Capability Unit to Against Natural Disaster.

6. Land Capability Unit for Drainage.

Drainage is an integral component in the design of development planning. This component has become public infrastructure needed by the community, especially in cities in order to lead a comfortable, clean and healthy city life. Drainage means to drain, drain, remove, or divert water. Drainage generally functions as a control for surface water needs to improve and reduce muddy areas, waterlogging and flooding. The LCU Drainage analysis aims to determine the level of land capability to break rainwater naturally, so that the possibility of inundation either local or widespread can be avoided. This LCU map is an overlay of an elevation map, a slope map, and a rainfall map. 
Table 8. Land Capability Unit for Drainage in Manokwari Regency.

\begin{tabular}{|l|c|c|c|}
\hline \multicolumn{1}{|c|}{ District } & Poor (Ha) & Sufficient (Ha) & High (Ha) \\
\hline West Manokwari & & 7441 & \\
\hline South Manokwari & 804 & 18959 & \\
\hline North Manokwari & & 39885 & 26 \\
\hline East Manokwari & & 1856 & \\
\hline Masni & 4082 & 62164 & 13042 \\
\hline Prafi & 2444 & 37691 & \\
\hline Sidey & 11118 & 47843 & 13068 \\
\hline Tanah Rubuh & 8147 & 21689 & \\
\hline Warmare & 9652 & 34203 & \\
\hline TOTAL & 36247 & 271731 & \\
\hline
\end{tabular}

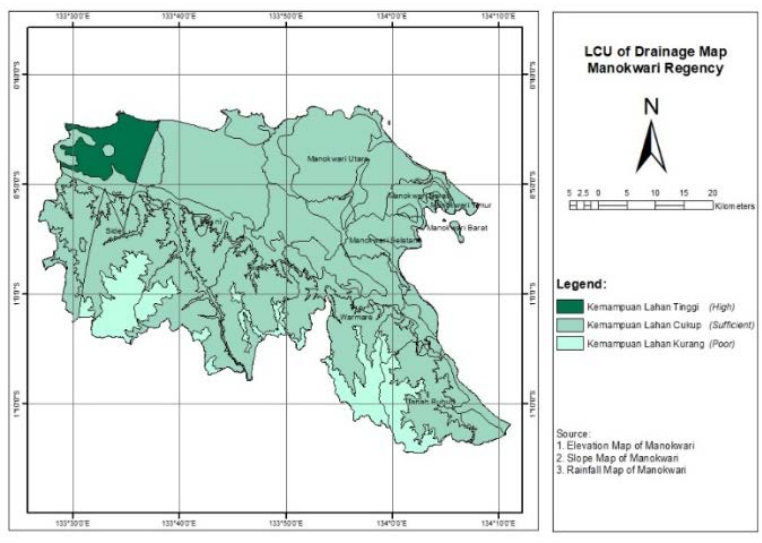

Figure 7. Land Capability Unit for Drainage.

7. Land Capability Unit of Waste Disposal. Waste disposal is an activity that is directly responsible for much environmental damage, and locating waste disposal sites, determining what waste materials were disposed of through time and exactly where, and determining ownership and whether disposal methods were proper or improper are important issues in environmental litigation. Therefore, Waste management (or waste disposal) includes the activities and actions required to manage waste from its inception to its final disposal.

Land Capability Unit (LCU) for waste disposal is a unit for identifying areas that can be occupied as a location for final storage and processing of waste, both solid and liquid waste. Some of the maps needed to make this LCU map are elevation map, slope map, rainfall map, and land use map.

Table 9. Land Capability Unit of Waste Disposal in Manokwari Regency.

\begin{tabular}{|l|c|c|c|c|c|}
\hline \multicolumn{1}{|c|}{ District } & $\begin{array}{l}\text { Low } \\
(\mathbf{H a})\end{array}$ & Poor $\mathbf{( H a )}$ & Moderat (Ha) & Sufficient (Ha) & High (Ha) \\
\hline West Manokwari & 1376 & 1750 & 4316 & & \\
\hline South Manokwari & 882 & 3347 & 35 & 4253 & 804 \\
\hline North Manokwari & 148 & 8298 & 31439 & & \\
\hline Manokwari Timur & 436 & 1102 & 318 & & \\
\hline Masni & 2520 & 26060 & 9604 & 24005 & 4082 \\
\hline Prafi & 3479 & 36 & 6021 & 20360 & 2444 \\
\hline Sidey & 13219 & 6379 & 5916 & 35244 & 11139 \\
\hline Tanah Rubuh & 303 & 2543 & 3030 & 15810 & 8147 \\
\hline Warmare & 281 & 6329 & 7888 & 19705 & 9652 \\
\hline TOTAL & 22644 & 55844 & 68567 & 119377 & 36268 \\
\hline
\end{tabular}




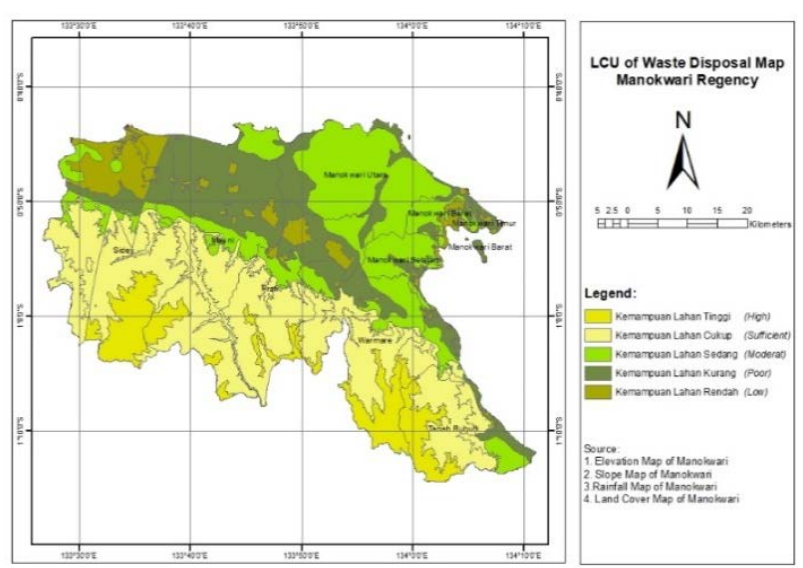

Figure 8. Land Capability Unit of Waste Disposal.

8. Land Capability Unit to Against Erosion.

Natural rates of erosion are controlled by the action of geological weathering geomorphic drivers, such as rainfall. The rates at which such processes act control how fast a surface is eroded. Typically, physical erosion proceeds fastest on steeply sloping surfaces, and rates may also be sensitive to some climatically-controlled properties including amounts of water supplied (e.g., by rain), storminess, wind speed, wave fetch, or atmospheric temperature.

Land Capability Unit (LCU) Against Erosion is useful for determining the level of soil erosion in the area or planning area, knowing the resistance of land to erosion, obtaining an overview of the limits at each level of its ability to erosion. Knowing the areas that are sensitive to erosion and the estimated deposition of the results of this erosion in the downstream. Some of the maps needed to make this LCU map are rainfall map, soil type map, morphological map, and slope map.

Table 10. Land Capability Unit to Against Erosion in Manokwari Regency.

\begin{tabular}{|l|c|c|c|}
\hline \multicolumn{1}{|c|}{ District } & Poor (Ha) & Sufficient (Ha) & High (Ha) \\
\hline West Manokwari & 270 & 7171 & 3853 \\
\hline South Manokwari & 3167 & 12743 & \\
\hline North Manokwari & 5418 & 34467 & 28867 \\
\hline East Manokwari & 16 & 1840 & 22883 \\
\hline Masni & 26288 & 11128 & 49452 \\
\hline Prafi & 10533 & 6748 & 20699 \\
\hline Sidey & 15695 & 6856 & 26296 \\
\hline Tanah Rubuh & 2648 & 6405 & 152050 \\
\hline Warmare & 6567 & 10990 & 0 \\
\hline TOTAL & 70602 & 98348 & pre \\
\hline
\end{tabular}

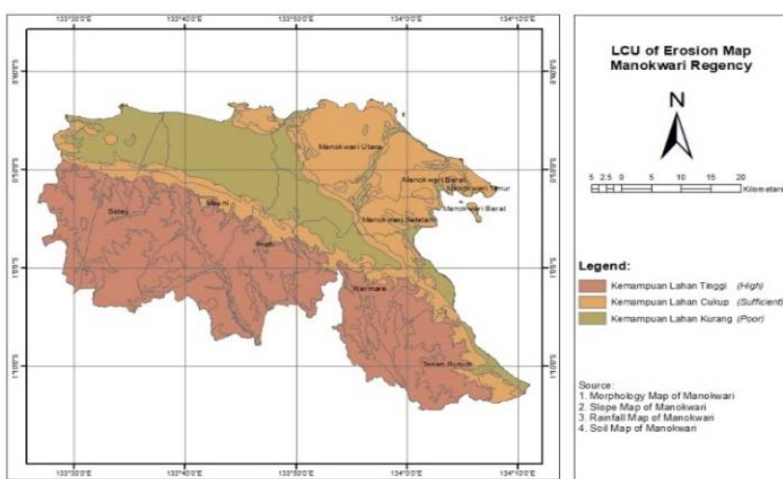

be excavated/ripened in the process of area development. In conducting this LCU analysis, the input is required in the form of an elevation map, slope map, and soil type map which is overlaid and produces an easy workable LCU map.

Figure 9. Land Capability Unit to Against Erosion.

9. Land Capability Unit of Ease of Work.

Easy workable LCU functions to determine the level of ease of land in the area and / or area to

Table 11. Land Capability Unit of Ease of Work in Manokwari Regency.

\begin{tabular}{|l|c|c|c|}
\hline \multicolumn{1}{|c|}{ District } & Poor (Ha) & Moderat (Ha) & High (Ha) \\
\hline West Manokwari & & & 7444 \\
\hline South Manokwari & & 3853 & 15930 \\
\hline North Manokwari & & & 39887 \\
\hline East Manokwari & & & 1857 \\
\hline Masni & 4007 & 29695 & 32611 \\
\hline
\end{tabular}




\begin{tabular}{|l|c|c|c|}
\hline \multicolumn{1}{|c|}{ District } & Poor (Ha) & Moderat (Ha) & High (Ha) \\
\hline Prafi & 102 & 22730 & 3775 \\
\hline Sidey & 216 & 37089 & 19730 \\
\hline Tanah Rubuh & 5 & 20775 & 9101 \\
\hline Warmare & 4735 & 21562 & 17549 \\
\hline TOTAL & 9065 & 135704 & 147884 \\
\hline
\end{tabular}

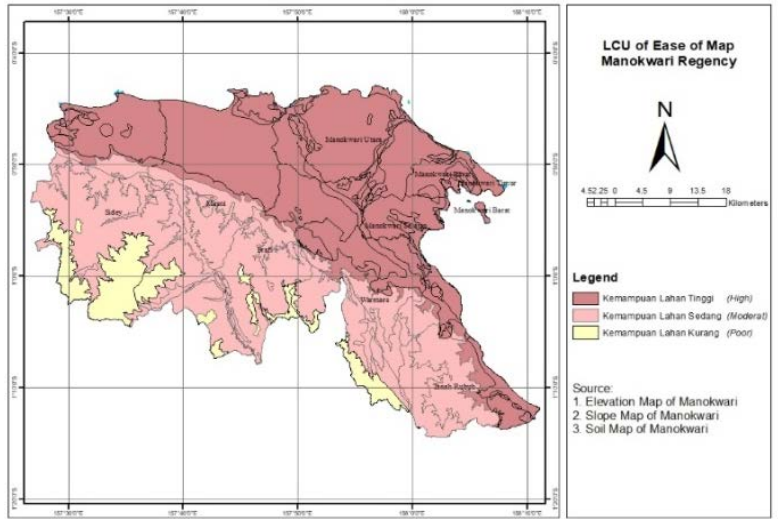

Figure 10. Land Capability Unit of Ease of Work.

10. Land Capability in Manokwari Regency.

The land capability classification in the research area is intended to know the description of the land capability level of the 9 variables composing the land capability category. These variables are Morphology, Slope Stability, Foundation Stability, Water Availability, Disaster Vulnerability, Drainage, Waste Disposal, Against Erosion and Ease of Work.

Based on the analysis results of the overlapping method or overlaying the assessment or weighting of each existing criterion /variable, according to the flow of the analysis chart, it can find the total value or scores from each region, so that it can form a group of each region into several classes based on the total range of existing scores. From the results of the total assessment of all these variables, It can be seen that the range of values obtained is from 66 to 139 (Table 12). Based on this value, the ability to develop land in urban areas in the Manokwari Regency area is divided into 4 categories, namely: (1) High Development Capability, (2) Sufficient Development Capability, (3) Moderate Development Capability and (4) Poor Development Capability.

The result of overlaying 9 LCU maps that have been calculated the weight produces a development capability map as shown in the Figure 11.

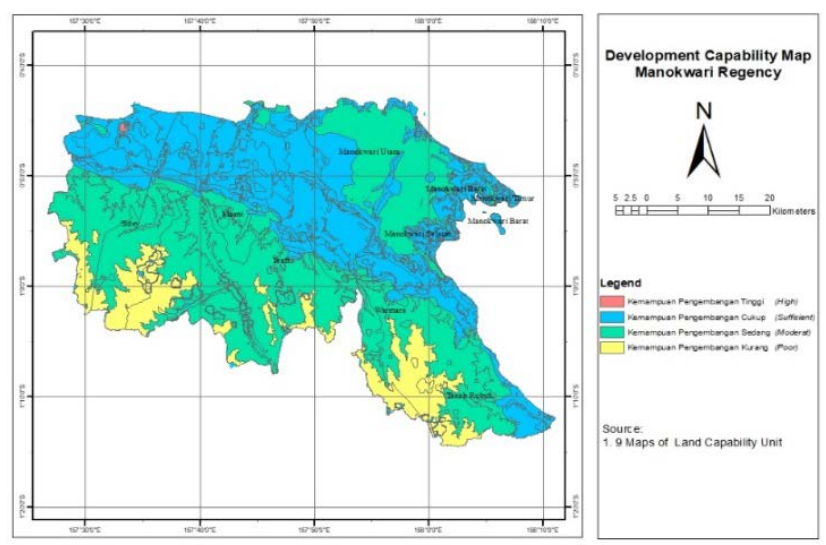

Figure 11. Development Capability Map of Manokwari Regency

Table 12. Land Capability in Manokwari Regency

\begin{tabular}{|c|c|c|c|}
\hline $\begin{array}{c}\text { Total } \\
\text { Value }\end{array}$ & $\begin{array}{c}\text { Urban } \\
\text { Development } \\
\text { Capability }\end{array}$ & $\begin{array}{c}\text { Land } \\
\text { Capability } \\
\text { Class }\end{array}$ & $\begin{array}{c}\text { Area } \\
\mathbf{( H a )}\end{array}$ \\
\hline $66-80$ & $\begin{array}{c}\text { Poor Development } \\
\text { Capability }\end{array}$ & Class b & 40216 \\
\hline $85-109$ & $\begin{array}{c}\text { Moderate } \\
\text { Development } \\
\text { Capability }\end{array}$ & Class c & 159557 \\
\hline $111-134$ & $\begin{array}{c}\text { Sufficient } \\
\text { Development } \\
\text { Capability }\end{array}$ & Class d & 111063 \\
\hline 139 & $\begin{array}{c}\text { High Development } \\
\text { Capability }\end{array}$ & Class e & 213 \\
\hline
\end{tabular}

\section{CONCLUSION}

Based on the description above, it can be concluded that the land capability class in Manokwari Regency is much influenced by an inhibiting factor in the form of a slope factor. This inhibiting factor can be seen in the identification process of the 9 Land Capability Units (LCU) described above. The land capability class also shows differences in land characteristics. Through a weighting system based on secondary data obtained from the Regional Planning and Development Agency (BAPPEDA) of Manokwari Regency, It can be seen that the research area is divided into 4 classes of land capability, namely poor, moderate, sufficient, and high development capability. 


\section{ACKNOWLEDGMENT}

All praises go to God Almighty, to the beloved campus of Pancasila University, to all lecturers, to BAPPEDA Manokwari Regency, to families and all parties who have helped and provided support from the initial stages of research to completion.

\section{REFERENCES}

Abdel Rahman M.A.E, Natarajan A., and Hegde R. (2016). Assessment of land suitability and capability by integrating remote sensing and GIS for agriculture in Chamarajanagar district, Karnataka, India. The Egyptian Journal of Remote Sensing and Space Sciences. 19(1), p. 125-141

Alikodra HS. (2012). Konservasi Sumberdaya Alam dan Lingkungan Pendekatan Ecosophy bagi Penyelamatan Bumi. Yogyakarta. Gadjah Mada University Press

Alvarado R, and Toledo E. (2017). Environmental degradation and economic growth: evidence for a developing country. Environment, Development and Sustainability. Springer. 19(4), p.12051218

Arifin, Bustanul. (2001). Pengelolaan Sumberdaya Alam Indonesia: Pendekatan Ekonomi, Etika, dan Praksis Kebijakan. (Natural Resources Management in Indonesia: Approach on Economics, Ethics and Policy Praxis). Jakarta. Erlangga.

Arsyad S. (2006). Konservasi Tanah dan Air. IPB Press, Bogor.

Asdak, C. (2007). Hidrologi dan Penglolaan Daerah Aliran Sungai. Yogyakarta. Gadjah Mada University Press.

Aziz S. (2008). Evaluasi Kemampuan Lahan dan Pendugaan Erosi untuk Arahan Pemanfaatan Lahan Di Sub DAS Juwet dan Dondong, Gunung Kidul yogyakarta. Thesis. Program Studi Geografi Pasca Sarjana Universitas Gadjah Mada. Yogyakarta.

Chowdhury M.N.M., Uddin S., Saleh S. (2014). Present scenario of renewable and nonrenewable resources in Bangladesh: A compact analysis. International Journal of Sustainable and Green Energy. 3(6), p. 164-178.

Christady H. (2007). Penanganan Tanah Longsor dan Erosi. Yogyakarta. Gadjah Mada University Press.

Departemen Kehutanan, Ditjen RRL (1986). Petunjuk Pelaksanaan Penyusunan Rencana Teknik Lapangan
Rehabilitasi Lahan dan Konservasi Tanah. Jakarta. Departemen Kehutanan.

Gashaw T, Tulu T, Argaw M, Worqlul A.W. (2018). Land capability classification for planning land uses in the Geleda watershed, Blue Nile Basin, Ethiopia. Modeling Earth Systems and Environment. Springer. 4(2), p. 489-499.

Gottfried R.R. (1992). On Gardening and Human Welfare, or, The Role of Attitudes and Natural Capital in Sustainable Welfare. Journal of the Agriculture, Food, and Human Values Society. Springer. 9(4), p. 36-47.

Hardjowigeno, S. (1985). Dasar-Dasar IImu Tanah. PT. Jakarta. Medyatama Sarana Perkasa

Hardjowigeno, S. (2018). Evaluasi Kesesuaiann Lahan dan Perencanaan Tataguna Lahan. Yogyakarta. Gadjah Mada University Press.

Kartasapoetra, G., A.G., Kartasapoetra, dan M.M., Sutejo. (2005). Teknologi Konservasi Tanah dan Air. Edisi Kelima. Jakarta. Penerbit Rineka Cipta.

Klingebiel, A.A., and P.H. Montgomery. (1961). Land Capability Classification. Agric. Handb. No.210, SCS-USDA, Washington.

M. Amin Diha, Go Ban Hong dan H. Bailey. (1996). Dasar-Dasar IImu Tanah. Universitas Lampung, Bandar Lampung.

Marpaung L.A. et al. (2008). Kebijakan Pengelolaan Sumberdaya Air dalam Hubungannya dengan Otonomi Daerah (Studi di Provinsi Lampung). Jurnal Pranata Hukum. Universitas Bandar Lampung. 3(2), p. 92-118.

Mary Silpa T.J, and Nowshaja P.T. (2016). Land Capability Classification of Ollukara Block Panchayat Using GIS. Procedia Technology, 24, p. 303-308.

Maryati S. (2013). Land Capability Evaluation of Reclamation Area in Indonesia Coal Mining Using LCLP Software. Procedia Earth and Planetary Science. 6, p. 465473.

Prahasta E. (2011). Tutorial ArcGIS Desktop untuk Bidang Geodesi dan Geomatika. Penerbit Informatika, Bandung.

Osly, P.J., Ihsani, I., Ririhena, R.E., Araswati, F.D. (2019). Analisis kebutuhan dan Ketersediaan Air Kabupaten Manokwari Dengan Model Mock. Jurnal Infrastruktur, 5(2), 59-67. 
Osly, P.J., Ririhena, R.E., Ihsani, I., Dwiyandi, F. (2019). Review Of Priority And Potential Agricultural Area Development. Jurnal of Critical Reviews, 6(5), 2394-5125.

Rayes, Luthfi (2006). Metode Inventarisasi Sumber Daya Lahan, Andi Yogyakarta.
Sitorus S.R.P. (2010). Land Capability Classification For Land Evaluation: A Review. Jurnal Sumberdaya Lahan. 4(2), p. 69-78.

Wirawan, R.R., Kumurur, V.A., Warouw, F. (2019). Daya Dukung Lingkungan Berbasis Kemampuan Lahan Di Kota Palu. Jurnal Spasial, 6(1), 2442-3262. 